University of Montana

ScholarWorks at University of Montana

$6-2010$

\title{
Orientation in Technological Space
}

\author{
Albert Borgmann \\ University of Montana-Missoula, albert.borgmann@umontana.edu
}

Follow this and additional works at: https://scholarworks.umt.edu/philosophy_pubs

Part of the Philosophy Commons

Let us know how access to this document benefits you.

\section{Recommended Citation}

Borgmann, Albert, "Orientation in Technological Space" (2010). Philosophy Faculty Publications. 8.

https://scholarworks.umt.edu/philosophy_pubs/8

This Article is brought to you for free and open access by the Philosophy at ScholarWorks at University of Montana. It has been accepted for inclusion in Philosophy Faculty Publications by an authorized administrator of ScholarWorks at University of Montana. For more information, please contact scholarworks@mso.umt.edu. 


\section{f i (3) $s+\mathbf{m} \not \tilde{n} \mathbf{d} @ \boldsymbol{\eta}$}

PEER-REVIEWED JOURNAL ON THE INTERNET

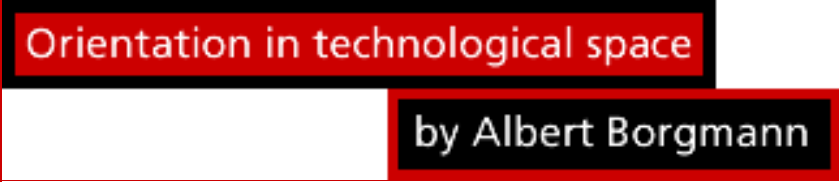

Orientation is crucial to human well-being. To be disoriented is to be in trouble, temporarily when we are confused, fatally if we are demented. Disorientation robs us of the distinctively human capacity to comprehend the world entire, if not individually and in practice, then certainly collectively and in principle.

Aside from the acute and evident problems of orientation, a cultural sort of disorientation is spreading today. To understand it, we need to see it in the context of time and space. Orientation is always an issue within a certain kind of space. The most general and rigorous theory of space is geometry. To orient yourself within it, you have to learn the axioms and theorems of the several kinds of geometry, and you do that by doing a lot of problems.

Physical space is an instantiation of one or another geometry. Theoretical and experimental physicists are the ones to discover the geometry of physical space, and they teach their students and attempt to tell the lay public how to be at home in cosmological and quantum spaces. Cultural space is in turn an instantiation of physical space, and to comprehend cultural disorientation and reorientation, we need to get a grip on cultural space.

It is a subtle and difficult question whether or how mathematical and physical space inform cultural space. It's helpful, as will be evident, to use certain terms of mathematics and physics in an informal way for purposes of cultural analysis. But time or, better, history is the context that best reveals how we struggle with orientation today.

Cultural space is a compound of spatial transformation and experience. Humans have always articulated space, by naming or by shaping []]. Spatial experience is the response to spatial articulation. Prior to the modern era, orientation was by landmarks. These could be as steady and prominent as mountains or as subtle and shifting as the patterns of the wind that the I nuit and the Polynesians had learned to read on trackless snow or water. They could be as spectacular as the sun, and the word orientation in fact has its origin in taking one's bearing from the rising sun, a sole oriente as the Romans had it.

Cultural landmarks had been more important, however, for as far back as the human condition has been visible to us from archeology and from the hunting and gathering cultures that had survived into the modern era. There was usually one thing that marked and centered the land above all others. It could be as simple as the sacred pole, planted over and over again by a nomadic people, or it could be as elaborate as the Parthenon in the sacred precinct of the Acropolis [2]. Genuine human well-being is always both physical and ethical, and the pre-modern landmarks provided both material and moral orientation. The crucial landmark in particular marked the place where one was at home, in the right place, and at peace with the world. A person displaced from that center would be at pains to get back home. The Odyssey is the story of homecoming, of nostos, as we are told in the opening lines of the epic. Nostalgia is the pain of not being able to return home.

Johannes Hofer coined the term in 1688 in the dissertation he wrote as a candidate for the degree of medical doctor at the University of Basel in Switzerland [3]. He thought of nostalgia as the medical condition that he particularly found among the young mercenaries from the Swiss mountain villages whose appearance is preserved in the Papal Swiss Guard and whose affliction has come down to us in Heidi.

Almost exactly a hundred years later, Immanuel Kant in 1786 raised the question: "What does it mean to orient oneself in thought?" [4] Kant was not in a position to suffer from nostalgia since he never left his hometown of Königsberg. Hofer held that the only cure for nostalgia was the return to what was so painfully missed - one's homeland. Kant agreed, but thought that the cure was not the recovery of the beloved home. To be cured, in Kant's view, was to be disabused of the illusion that one's home is the 
object of desire when in fact it is one's youth. Hence, you can't go home again. And yet Kant must have sensed that more than the futile attempt to recover one's youth was at issue in nostalgia, for he noted that homesickness more often befell those who had left a community of simple circumstances and vital kinship. People who are devoted to making money, Kant said, live by the adage: Patria ubi bene - my homeland is where I'm doing well [ $\underline{5}]$.

Kant saw deeply into the character of modernity, and taking up the challenge of orientation that had occupied him already in 1768, he clearly saw that the traditional physical and ethical landmarks had been losing their authority and that a new method of orientation was needed [ 6 ]. Kant's proposal was as insightful as his diagnosis. In his 1768 essay, he proposed that we think of physical space as structured by a three-dimensional coordinate system, centered on the human subject so that, using contemporary terminology, we can identify right and left with the positive and negative $x$-axis, front and back with the positive and negative y-axis, and up and down with the positive and negative z-axis. Voilà: Ego est origo - the human ego is the orienting origin of space.

Again, using contemporary terminology, we can elaborate Kant's proposal this way. Without the orienting center of the human subject or ego, space would be an isotropic, i.e., an endless and indifferent threedimensional grid. In this 1786 essay, Kant limited himself to human handedness or chirality, as the origin of orientation. Crucially, however, he linked moral to material orientation. The space of ethical authority, Kant held, was by itself as devoid of orientation as physical space, and here too it was the task of the human subject to establish orientation through the moral law that reason imposes on itself. Morality is self- legislation, i.e., autonomy, for Kant.

Kant's prescient understanding of modern space was at odds with the actual space and the spatial dealings of his time. Physically traversing space was no quicker or easier in much of the eighteenth century than it had been in the Roman Empire. Good roads and fresh horses were the best you could hope for on land; swift sailing ships and favorable winds were the most you could expect on water. Sending information across space had to be done by visual signals - a precarious channel of miniscule bandwidth.

Still in Kant's lifetime, the application of coal, steam, and steel to the railroad initiated the conquest and homogenization of physical space that Kant had foreseen. The effect on the structure of experiential space was especially powerful on the North American continent. Distances that had previously been marked by arduous and perilous months shrank to pleasant days. But the moral impact of the railroads was just as powerful if by moral we mean the habitual and customary as well as the ethical and normative conditions of life.

A far-flung system of railroads would have collapsed under confusion and complexity without the rational organization of time and work. Local time is centered on high noon, the moment when the sun reaches its highest point on any particular day. But local time changes as you cross the longitudes, and if a train stops at a dozen different places going from Whitefish, Montana to Seattle, Washington, a schedule based on local times would have to account for a dozen different times separated by unequal intervals. The solution was the imposition of time zones and standard time.

The railroad brought another kind of order in its train. As the railroad lines and nets grew, they required a new kind of organization - the corporation. Just as standard time superseded local time, so the corporation displaced personal ownership. A business owned by an individual and identified with him is as limited and vulnerable as the person himself. A corporation is unlimited in time and can occupy a wide economic space due to its hierarchical structure, its clear divisions of responsibility, and its ability to raise capital from across a continent and even from across the world [7]].

The corporation can be thought of as the paradigm of ordering the space of culture in the late nineteenth century, furnishing a template of rigor and coordination for what was so far unique and diverse [8]. It transformed the market from a communal gathering place into an all-encompassing machinery for the allocation of resources and the distribution of benefits.

Incorporation in this broader sense reached its highpoint in the middle of the American century. It lent security and more than a little of their identity to the members of the middle class. It distinguished the owners of Fords from the owners of Chevys, the farmers who swore by Deere tractors from those who believed in International Harvester. General Electric shaped their dwellings with its appliances, and General Mills their eating habits with its foods. A family identified itself and its welfare with the breadwinner's employer. It was a General Motors or a Sears family.

The transformation of cultural space was followed by another reshaping of geographic space in the United States through the construction of the Interstate Highway system that was officially launched in 1956 and in the ensuing half-century covered the continent with a wavy grid of nearly 50,000 miles of Interstates, the ones running north and south named by odd numbers, the eastward and westward roads by even numbers.

These radical transformations of moral and material space showed undeniable vigor and rigor. Much energy and ingenuity was spent on organizing business, mining resources, producing raw materials, 
manufacturing goods, and bringing commodities to the attention of consumers. Canyons were excavated here and bridged there to open up a passage for the highways. And yet, although effort and discipline went into the shaping of technological space, the opposite of these traits came to characterize the use of these transformations. The space of common experience became more opaque and more accommodating. The corporate structure filled the shelves of department stores and supermarkets with diverse and alluring goods. But all that prosperity had lost its background of intelligibility. Goods were no longer the evident fruits of labor and cooperation. Bread no longer told of the baker's work. Clothing did not betray a tailor. Vegetables showed no trace anymore of a garden. Commodities appeared as if by magic.

Similarly, a trip to relatives some 200 miles distant did not involve you any longer in the towns and villages you previously had to cross on your way. There was no more impatience with the low speed limits and many stop signs of a particular city, nor was there an invitation to stop at the ice cream store on the thoroughfare of a certain hamlet. The Interstate reduced six hours of memorable variety into less than four hours of smooth and pleasant sameness. Places that once had been occasions of engagement became picturesque and distant scenes.

Orientation as the challenge of finding one's way through the world became easier in this newly structured world. Before the Interstates, it was likely that you would lose track of a highway as it wound its way through a town. Before Holiday Inns and their like sprang up, it was difficult to find predictable and appropriate lodging. Standardized supermarkets made it easy to find provisions. But ease and sameness grew together. Things began to look alike in all directions. Space became more isotropic.

In an obvious sense, the middle of the twentieth century increased the variety of experiences for Americans. If you lived in Chicago before the Second World War, going on vacation meant going to a lake in Wisconsin. After the War, middle-class Chicagoans went to see the Grand Canyon, the Florida coasts, Yellowstone Park, and before long, Disneyland. But uniformity undergirded and subverted variety. You'd see palm trees and lodge pole pines through the same windshield. You looked at the ocean and snowy peaks from the same motel window. You'd have hamburgers with fries in Jackson Hole as well as in Galveston.

Cultural isotropy differs from its rigorous cosmological cousin in two ways. First, cosmological isotropy is all or nothing. The universe is either isotropic or it's not. Culturally the look of sameness in all directions is a matter of degree. It can grow. Second, in cosmology, things look literally the same, nothing but clusters of galaxies at the largest and decisive scale. In culture, things are generically the same - the same kinds of motels, fast-food places, cars, houses, and furniture. So they are for the middle class with the lower class getting the left-overs and the upper class setting the new standards of prosperity.

In the late forties and early fifties, the supporting structure of sameness was still visible. People had a sense of the wide grid of the Interstates. They learned to identify exits by the number of miles they were distant from the state border. They knew how to count the streets and avenues when looking for an address. They had come to think of the large corporations as permanent hierarchies that assigned them their place as workers or managers. American Telephone and Telegraph had taught them by financial means to distinguish between local calls and long distance calls. Foreign stood out from domestic goods by their rarity and price.

At the same time, television began to spread through American culture. At first, it accentuated the more or less traditional structure of cultural space. As a technological device it was initially fascinating and gathered neighbors and the family around itself. Businesses, communities, in fact the entire country, were united by watching the same comedians, singers, and Westerns. Fascination faded, however, as television sets became more ubiquitous and programs more numerous.

The enduring effect of television on technological space was a still more incisive in loosening the ties between the origin and the presence of all the items that furnish and populate everyday life. Politicians and entertainers appeared with equal ease and celebrity on the surface of the cathode-ray tubes. So did scenes of paradise and scenes of destruction. How the face of a President in the White House could appear as a pattern on a vitreous surface was beyond most people's comprehension. That they could follow a baseball game, being played a thousand miles away, in their living room was something that they came to take for granted.

The crucial and in many ways final factor in the transformation of technological space was the personal computer. It became the common portal to cyberspace. To understand its effect on the problem of orientation we have to conscript another technical term for cultural analysis. It's the distinction in geometry between metric and topological spaces. The Euclidian spaces we were taught to comprehend in high school are metric. They have measurable distances and thus presuppose a rigidity that makes it possible to determine the quantities of distances, surfaces, and volumes. Topology is sometimes called "rubber sheet geometry" because deformations by stretching or compressing are irrelevant. What remains definite are relations and continuities.

As in the case of isotropy, the distinction between topology and metric geometry is all or nothing. A geometrical space is either topological or metric []․ In the culture of technology, there is a gradual 
softening of the rigor of distances. It began with the railroad that in the experience of travelers compressed distances by a factor of 20 or more. The telegraph was an early case where distance in time shrank to nearly zero though distance expressed in the money, paid for a message, remained formidable. Ever more powerful and comfortable automobiles and ever smoother and more direct roads increased the topological elasticity of space.

Television, of course, brought the distant near in both image and sound. But like the early railroad, it was limited and selective in its topological reach. The Internet did for information what the automobile did for transportation - it opened up what was heretofore inaccessible. But unlike the automobile and the Interstate System, the Internet did not just render distances pliable, it altogether eliminated distances.

Cyberspace is basically topological. It has structure, to be sure. There is linking, nesting, and clustering. And its subspaces, i.e., the particular sites, are metric. But all sites are equally near and far. They are located in a distanceless space.

In an obvious sense, we now divide our lives among three different kinds of cultural spaces. In unfamiliar surroundings, we still rely on the grids of technological space. We count streets or traffic lights and numbered floors to find an office or our new apartment. But familiarity creates an island of oriented space. We come to know the buildings and the corners, the forks and the intersections. We stop counting blocks and reading signs. We feel at home.

Much of our time is spent in the topology of cyberspace. One might wonder at our easy familiarity with a space without distances. Yet the spaces of imagination, desire, and magic have always been distanceless though they have not been topological since they have no reliable structure. Here too there seems to be an obvious division of spatial experience. The screen is the scene of topological cyberspace. But as soon as we step away from the computer, we move within metric space. Steps, after all, are the original ways and measures whereby we appropriate metric space. Underlying these divisions and distinctions, however, there is a novel and pervasive sense of cultural space. The topological space of the Internet has invaded and transformed cultural space in its entirety. The effect has been so profound that it's difficult now to remember or imagine the world before or without the Internet.

The negative effects of cyberspace are well-defined and well-attended, to be sure - identity theft, cyber stalking, imprudent self-exposure, and needless and endless complications in deciding on insurance, communication links, and financial savings. The personal computer as well as the cell phone and the automobile have a confusing plethora of features that requires you to study the manual unless you are a teenager who takes, even if he does not have, the time to explore and play with the device from one end to the other.

The offenses against security and ease of operation are of concern to the government and to designers. A more publicly transparent Internet will provide greater security, and devotion to ergonomics will see to it that the uncharacteristic obtrusiveness of the complex electronic machinery into the surface of the user's world will be reassigned to its more usual discreetness in the service of the layperson's intuitions.

Similarly, the ruinous complexity of financial instruments that escaped intelligibility and responsibility will be reined in by governmental regulation and oversight.

The culturally more interesting and morally more consequential effects of cyberspace are its comforts which we find ourselves unable to resist. The global effect is comparable to a luminous haze that is gilding and softening the contours of reality. It simultaneously secludes us from all that is unpleasant and allows us to fill in the remaining silhouettes of things and persons in whatever way we desire. The real world as a whole is occluded while limited regions stand out in preternaturally vivid detail.

An iPod shields you from the chaotic and unpredictable acoustic environment at large and indulges you with your favorite music. Amazon.com spares you the walk past buildings that depress you and people you'd rather not encounter on your way to the bookstore where a clerk will give you limited and unreliable information about the book you're interested in. On Amazon.com, the information is instantaneous and rich, and a purchase is done with one click. The GPS device in your car makes it unnecessary for you to consult a map, stop at a gas station, count miles, or look out for signs and landmarks. The exterior world becomes irrelevant while computers keep the interior of your car pleasant and entertaining. Persons become tentative outlines when you meet them in reality and finely resolved images when you're back at your computer to Google what's of concern to you. Your knowledge of history and geography has become slack. The need to know is replaced by pieces of information that are summoned from nowhere and dissolve into nothing.

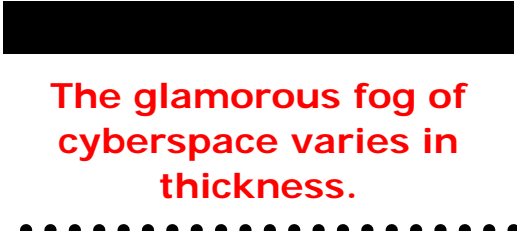


The glamorous fog of cyberspace varies in thickness. It's denser when we sit in front of the computer than when we are face to face with a person. It's thinner for the driven and the ambitious than for the sullen and the addicted. But when it is thick, it's disorienting in a new and distinctive way. The problem is not that we can't find what we are looking for, but that we are not sure what to look for in the first place. Whatever we have summoned to appear before us is crowded by what else is ready to be called up. When everything is easily available, nothing is commandingly present. The rigor of the coordinate version of technological space has yielded to the pleasures of the isotropic and topological phase of technological space, i.e., to cyberspace.

The disorientation that is the response to cyberspace has an addictive quality that like other addictions may well be the consequence of a natural desire that has lost its natural and cultural checks. Sexual desire is a condition of survival for a species. In human history, it was checked by the needs of loyalty and the limits of opportunity. Not so in the case of cyber pornography. The desire for information too is crucial for human welfare. But the information you could gather from clouds, tracks, and sojourners was limited, and information brought to life from writing or print was limited as well, and it required skill and focus. Information on the Internet is limitless and easy.

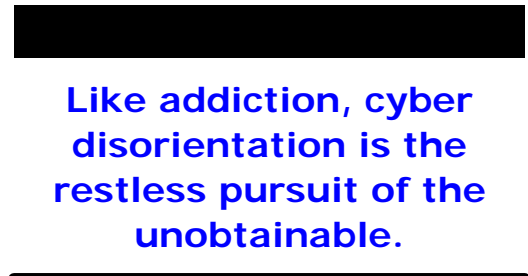

Like addiction, cyber disorientation is the restless pursuit of the unobtainable. The Internet inflames and disappoints the desire for news in an endless cycle of ever more diverse and seductive news. Disorienting addiction can have grave consequences when a youngster gets lost in video games or the global economy gets trapped in speculations. We're ready to recognize and remedy such calamities. What remains largely unattended is the mild and pervasive disorientation that secludes us from one another and occludes the burdens and blessings of reality.

Since cyber disorientation is a subclinical malaise rather than a raging fever, it can be ignored while it depresses the depth of life. Dire warnings are therefore misplaced. We don't find ourselves helplessly lost in a dark room - the predicament Kant sets before us as the challenge of orientation [10]. We move around in the pleasant and ever promising space of ready information. Yet we must feel sorrow at the spreading shallowness and restlessness of life.

How can we hope to become grounded again? Is the Kantian proposal a sound remedy? Can we freely impose our ego as the origin of material and moral coordination? There is a profound ambiguity in Kant's proposed orientation. Prima facie it looks like the exemplar rather than the cure of disorientation - the illusion that the unencumbered self can autonomously decide where it wants to be, what it wants to do, and whom it wants to be with [1]1].

But as in his discussion of nostalgia, Kant betrays in an aside insight that is deeper than his official pronouncement. "In darkness", Kant says, "I can orient myself in a familiar room if only I can touch a single object whose location I remember." [12] Kant goes on to argue that such a reference to the arrangement of a space is insufficient and requires the left-right distinction to work. Martin Heidegger has rightly replied that the recollection of that object in space is in fact a trace of the oriented world we always and already find ourselves in [13]. The meaningful order of the world is contingent rather than a priori. It is discovered rather than imposed. Left is where the heart is. You find out rather than make up your particular handedness.

Still, Kant is right in anchoring orientation in the immediacy of my here and now. Some of us are in the fortunate position of being able to say: Ubi antecessores ibi patria - my home is where my ancestors have been. But for many of us, it's per contingentiam ad patriam - homecoming happens through contingency. The education we received, the spouse we met, the opportunities that opened up, it all seems to have turned on chance happenings, and yet it all has converged on a deep and definite place.

Or has it? Homesickness seems to be a thing of the past; Swiss nostalgia certainly is. The youngsters born in Zermatt or Törbel today grow up in a world of tourism and among strangers more often than among fellow villagers. But there is still the subliminal nostalgia for a firm and consoling place [14]. That generalized homesickness surfaces in the Christmas cards we send one another. The scenes are of the last times and places when people had ancestral homes, the villages and towns of the Victorian era.

Orientation today must be centered in actual homes, the places we embrace through active engagements. Such engagements must be focal, occasions that are good for nothing because they are good in themselves, the dinner in the evening, music on the weekends, the garden during the summer. There is a literature of focal things and practices, about gardening, cooking, running, fly fishing, music making, and 
more. The proverb Kant reminds us of ubi bene ibi patria can point us to the right place if what goes with bene (well) is acting well rather than doing well.

Focal, however, does not mean self-centered or exclusive. Focal activities have to radiate out into the wider world and disclose its pitfalls and landmarks. We can think of a focal practice as a clearing in the mist of busyness, a clearing that first reveals the here and now and then, we may hope, will spread to reveal the world at large. We can recover orientation from the luminous haze of hyperinformation if what is lifting is the fog of distraction and what remains is the light of information.

\section{About the author}

Albert Borgmann is the Regents Professor of Philosophy at the University of Montana. E-mail: albert [dot] borgmann [at] umontana [dot] edu

\section{Notes}

1. Yi-fu Tuan, Space and place: The perspective of experience. Minneapolis: University of Minnesota Press, 2001 (1977).

2. Mircea Eliade, The sacred and the profane: The nature of religion. Translated by Willard R. Trask. New York: Harper \& Row, 1959 (1957).

3. Johannes Hofer, Dissertatio medica de nostalgia, oder Heimwehe. Basel: Jacob Bertsch, 1688.

4. Immanuel Kant, "Was heißt: sich im Denken orientieren?" Was ist Aufklärung? Ausgewählte kleine Schriften. Edited by Horst D. Brandt. Hamburg: F. Meiner, 1999 (1786), pp. 43-61.

5. Kant, "Anthropologie in pragmatischer Hinsicht," Schriften zur Anthropologie. Edited by Wilhelm Weischedel. Frankfurt: Suhrkamp, 1977 (1798), p. 481.

6. Kant, "Von dem ersten Grunde des Unterschiedes der Gegenden im Raume," Vorkritische Schriften bis 1768. Edited by Wilhelm Weischedel. Frankfurt: Suhrkamp, 1977 (1768), pp. 991-1,000.

7. Alfred D. Chandler, The visible hand: The managerial revolution in American business. Cambridge, Mass.: Belknap Press, 1977.

8. Alan Trachtenberg, The incorporation of America: Culture and society in the gilded age. Twenty-fifth anniversary edition. New York: Hill and Wang, 2007.

9. For a scientific illustration of the topological-metric distinction, see Frank Wilczek, The lightness of being: Mass, ether, and the unification of forces. New York: Basic Books, 2008, pp. 102-103.

10. Kant, "Was heißt: sich im Denken orientieren?" p. 48.

11. Michael Sandel, Liberalism and the limits of justice. Cambridge: Cambridge University Press, 1982.

12. Kant, ibid. My translation.

13. Martin Heidegger, Sein und Zeit. Tübingen: M. Niemeyer, 1960 (1927), pp. 109-110.

14. Edward S. Casey, “The world of nostalgia," Man and World, volume 20, number 4 (1987), pp. 361-384.

\section{Editorial history}

Paper received 4 May 2010; accepted 10 May 2010. 
Orientation in technological space

by Albert Borgmann.

First Monday, Volume 15, Number 6 - 7 June 2010

http://firstmonday.org/ojs/index. php/fm/rt/printerFriendly/3037/2568 